\title{
Paleoenvironment of the Late Cretaceous (Late Touronian-Early Campanian) Ostarcoda in the Kometan Formation, Dokan Area, Kurdistan region, NE-Iraq
}

\author{
Zardasht Ahmed Taha \\ Dept. of Geology, College of Science, University of Suleiman, \\ Kurdistan Region, NE-Iraq. \\ zardasht.taha@univsul.edu.iq
}

\begin{abstract}
In the present study, selected the Kometan Formation (Late Turonian - Early Campanian) from the Dokan area, NE-Iraq. In this formation studied Ostracoda and identified fifteen open Ostracoda species belonging to ten genera (Bairdia, Bairdiacypris, Bythocypris, Bairdoppilata, Cavellina, Cypridina, Cytherella, Haplocytheridea, Pterygocythereis, and Paracypris). The goal of the present study is to identify Ostracoda species under polarizing microscopes for the first time in the Kometan Formation in the Dokan area. The Ostracoda assemblage such as Bairdia, Bairdiacypris, Cytherella, Cypridina, and Paracypris with foraminifera species Globotruncana linneiana, Globotruncanita stuartiformis, Marginotruncana schneeansi, and Dicarinella asymetrica indicate the Kometan Formation deposited in the deep marine environment.
\end{abstract}

Keywords: Dokan area; foraminifera; Kometan Formation; (Late Turonian - Early Campanian); Northeast Iraq; Ostrcoda; Upper Cretaceous.

\section{Introduction}

The Upper Cretaceous Kometan Formation (Late Turonian - Early Campanian) consists of pelagic limestone (light gray to white, thin to thick-bedded Limestone) about 127 meters thick in the Dokan area, NE-Iraq (Taha, 2008; Karim \& Taha, 2009). It contains large scale stylolites and chert nodules in Dokan area (Karim et al., 2001; Taha, 2008). It was first described by Dunnington in 1953 at Kometan Village (Buday, 1980). The contact of the Kometan Formation is unconformable (Dunnington, 1953 in Bellen et al., 1959; Buday 1980). However, Karim et al., 2001; Taha, 2008; Karim \& Taha, 2009, studied this section and mentioned the contact (upper and lower) of the Kometan Formation is conformable. Previous works studied the Kometan Formation palaeontologically and biostratigraphically proved that the age of the formation is Upper Turonian - Lower Campanian depending upon foraminifer's assemblages (Chatton \& Hart, 1961; Buday, 1980; Kaddouri, 2001; AlKhafaf, 2005; Abawi \& Hammoudi, 2006 and Jaff et al., 2015). For the first time studied this section from the Dokan area to determine an identification of Ostracoda (thin section) under polarizing microscopes. 


\section{Geological Setting}

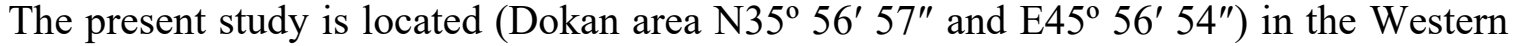
Zagros Fold-Thrust Belt (Buday, 1980; Buday \& Jassim, 1987; Jassim \& Goff, 2006). It is in the High Folded Zone (Buday \& Jassim, 1987). The Late Cretaceous formations in the present study from oldest to youngest consist of Qamchuqa, Dokan, Gulneri Shale, Kometan, Shiranish, and Tanjero formations (see Figure 1).

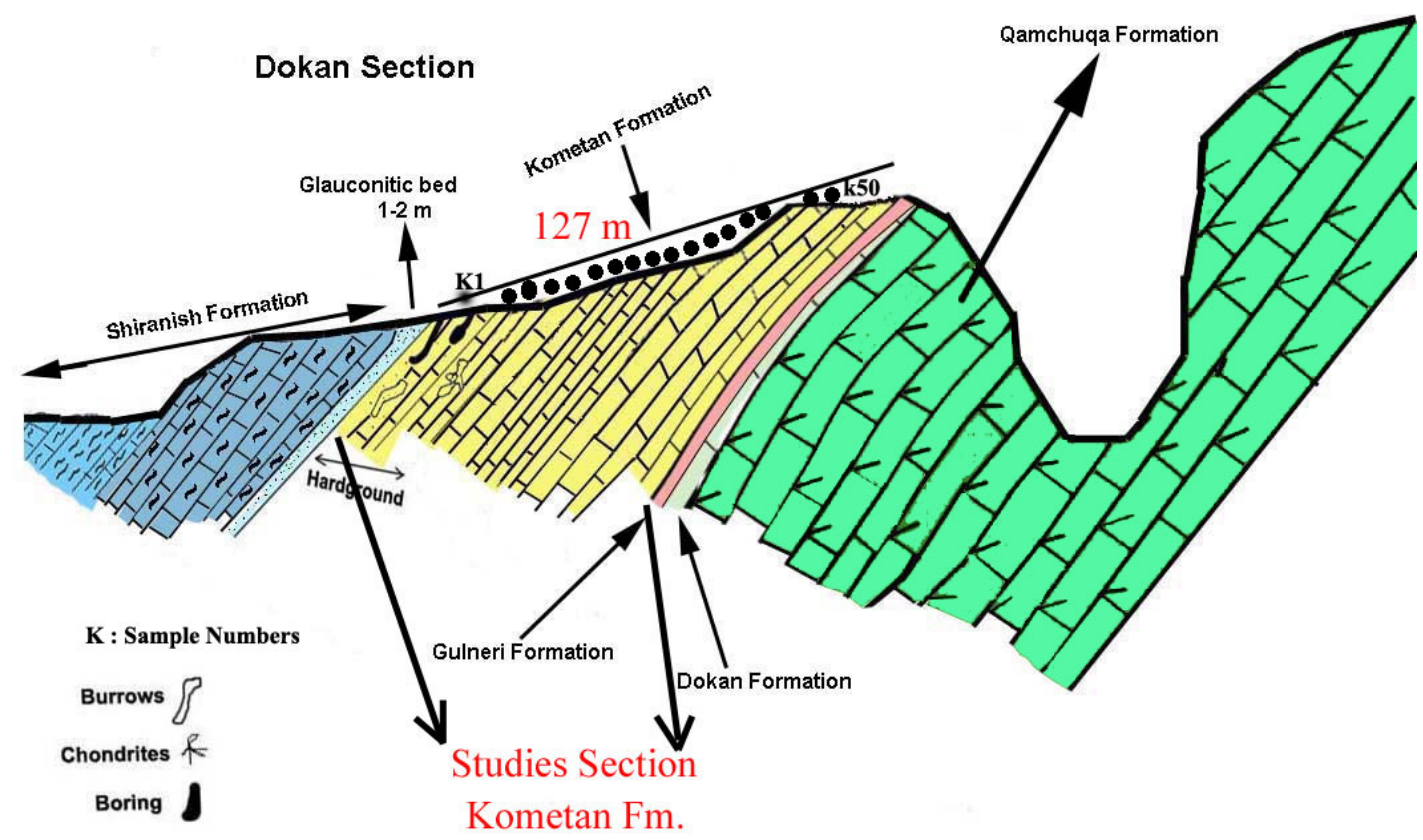

Fig. 1. Geological cross-section of the studied area (After Taha, 2008).

\section{Materials and methods}

Twenty samples were picked up from outcrops succession of the Kometan Formation in the Dokan section. Twenty thin sections were prepared. Identification of specimens was by using the polarizing microscope and photograph images were taken by a digital software program (Plates 1 and 2). The taxonomic determination of the species is based on the classifications by Sars (1866); Moore (1961) and Al-Shareef et al. (2010).

\section{Ostracoda in the studied section (Dokan area)}

The most familiar order of ostarcoda assemblage in the Upper Cretaceous is Podocopida Sars (1866), it comprises three suborders Podocopina, Platycopina, and Cladocopina (Moor, 1961) (see Figure 3). The Kometan Formation comprises a diverse assemblage of Podocopina and Platycopina. The Platycopida family is most abundant in this formation and with its genera of Bairdia, Bairdiacypris, Bythocypris, Cavellina, Cypridina, Cytherella, Haplocytheridea, Pterygocythereis, and Paracypris. Ostracoda is not easy to identify the species by thin section because of lack of distinguishing external characteristics 
such as free margin, outline, ornamentation, hinge, and muscle scars. Four genera Bairdia, Bythocypris, Cytherella, and Paracypris as index genera from the Upper Cretaceous Tanum, Khasib, Sa'di, and Mushorah formations in Northwest and middle Iraq (Al-Shareef et al., 2010).

\section{Age implications}

The paleontological data from the Dokan area suggest a Late Turonian to Early Campanian for the Kometan Formation and rich in planktic foraminifera (Kaddouri, 2001; Al-Khafaf, 2005; Jaff et al., 2015). The Ostracoda assemblage includes important forms like Bairdia, Bythocypris, Cypridina, and Paracypris, it is a determination as Late Turonian to Early Campanian, and these Ostracoda genera identified and recognized under a polarizing microscope (see table 1 and Figure 2).

Table 1. Ostracoda distribution during Upper Cretaceous (Turonian to Campanian) in the Kometan Formation, Dokan area compare with the other localities in Iraq.

\begin{tabular}{|c|c|c|c|}
\hline $\begin{array}{c}\text { Genera } \\
\text { (Present study) }\end{array}$ & Type species & $\begin{array}{c}\text { Other Formation } \\
\text { Al-Shareef et al., } 2010\end{array}$ & Age \\
\hline $\begin{array}{l}\text { Bairdia } \mathrm{M}^{\prime} \text { Coy, } \\
1844\end{array}$ & $\begin{array}{l}\text { Bairdia Curta M' Coy, } \\
1844\end{array}$ & Tanuma Formation & $\begin{array}{l}\text { Turonian } \\
\text { Campania } \\
\mathrm{n}\end{array}$ \\
\hline $\begin{array}{l}\text { Bairdiacypris } \\
\text { Bradfirld, } 1935\end{array}$ & $\begin{array}{l}\text { Bairdiacypris } \\
\text { hoxbarensis (Harlton, } \\
1927 \text { ) }\end{array}$ & / & $/$ \\
\hline $\begin{array}{l}\text { Bythocypris Brady, } \\
1880\end{array}$ & $\begin{array}{l}\text { Bythocypris reniformis } \\
\text { Brady, } 1880\end{array}$ & Mushorah Formation & $\begin{array}{l}\text { Campania } \\
\mathrm{n}\end{array}$ \\
\hline $\begin{array}{l}\text { ?Bairdoppilata } \\
\text { Coryell, Sample, and } \\
\text { Jennings, } 1935 \\
\end{array}$ & $\begin{array}{l}\text { Bairdoppilata martini } \\
\text { Coryell, Sample } \\
\text { andJennings, } 1935\end{array}$ & / & / \\
\hline $\begin{array}{l}\text { Cavellina Coryell. } \\
1928\end{array}$ & $\begin{array}{l}\text { Cavellina pulchella } \\
\text { Coryell, } 1928\end{array}$ & / & / \\
\hline $\begin{array}{l}\text { Cypridina Milne } \\
\text { Edwards, } 1840\end{array}$ & $\begin{array}{l}\text { Cypridina pyrocypris } \\
\text { Mueller, } 1890\end{array}$ & / & / \\
\hline $\begin{array}{l}\text { Cytherella Jones, } \\
1849\end{array}$ & $\begin{array}{l}\text { Cytherella ovate } \\
\text { (Roemer, 1841) } \\
\text { Bosquet, } 1860\end{array}$ & $\begin{array}{l}\text { Khasib, Tanum, and } \\
\text { Sa'di formations }\end{array}$ & $\begin{array}{l}\text { Turonian } \\
\text { Campania } \\
\mathrm{n}\end{array}$ \\
\hline $\begin{array}{l}\text { ?Haplocytheridea } \\
\text { Stepenson, } 1936\end{array}$ & $\begin{array}{l}\text { Haplocytheridea agilis } \\
\text { (Guan, 1978) }\end{array}$ & / & I \\
\hline $\begin{array}{l}\text { Paracypris Sars, } \\
1866\end{array}$ & $\begin{array}{l}\text { Paracypris abscissa } \\
\text { (Reuss, 1850) }\end{array}$ & Mushorah Formation & $\begin{array}{l}\text { Cenoman } \\
\text { ian } \\
\text { Campania } \\
\mathrm{n}\end{array}$ \\
\hline $\begin{array}{l}\text { Pterygocythereis } \\
\text { Baird, } 1850\end{array}$ & $\begin{array}{l}\text { Pterygocythereis jonesii } \\
\text { (Baird, 1850) }\end{array}$ & / & / \\
\hline
\end{tabular}




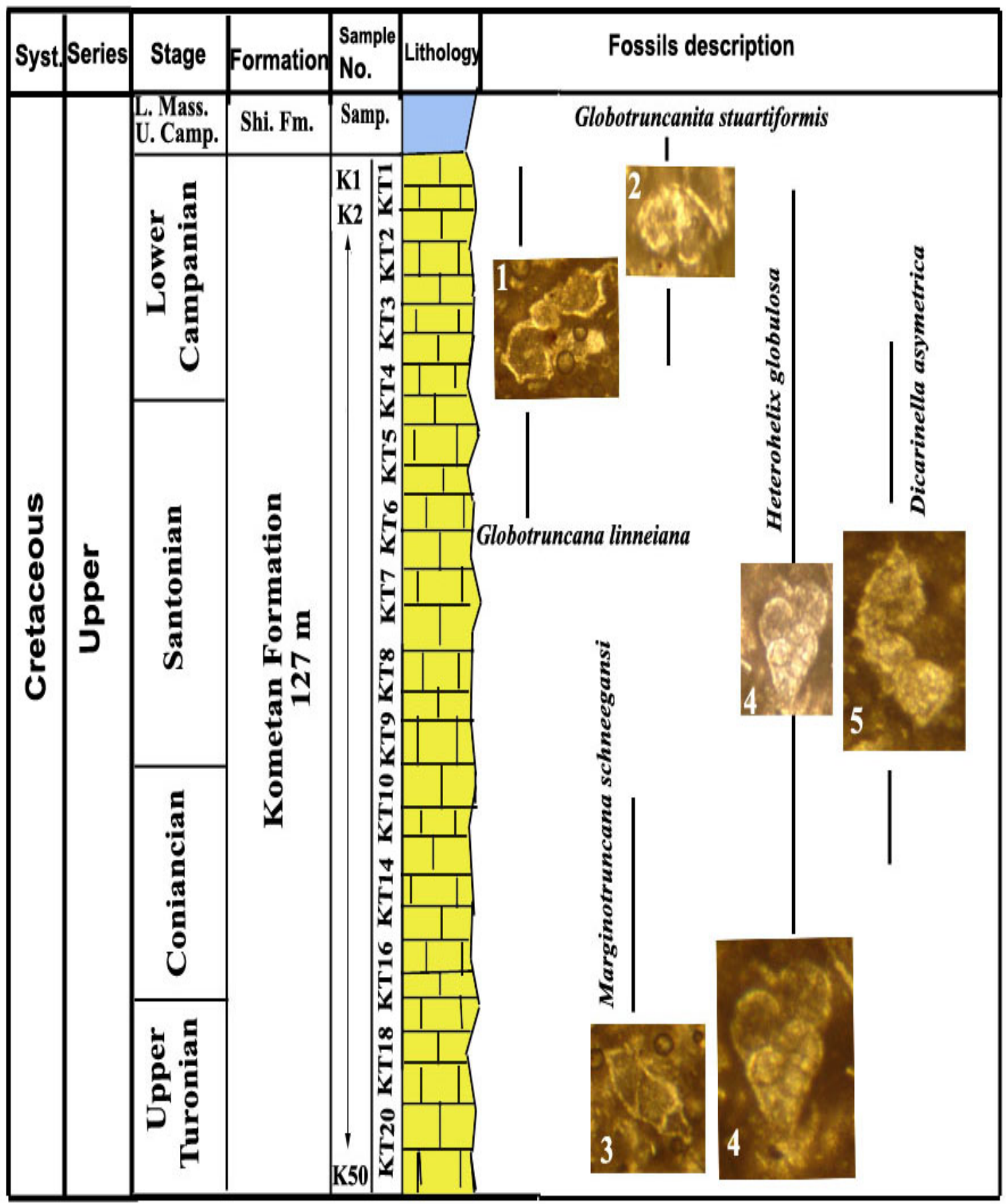

Fig. 2. A stratigraphic column with the key species of planktic foraminifera association with Ostracods in the Kometan Formation, Dokan section, Dokan area, Kurdistan Region, NE-Iraq (see Plate 3). 

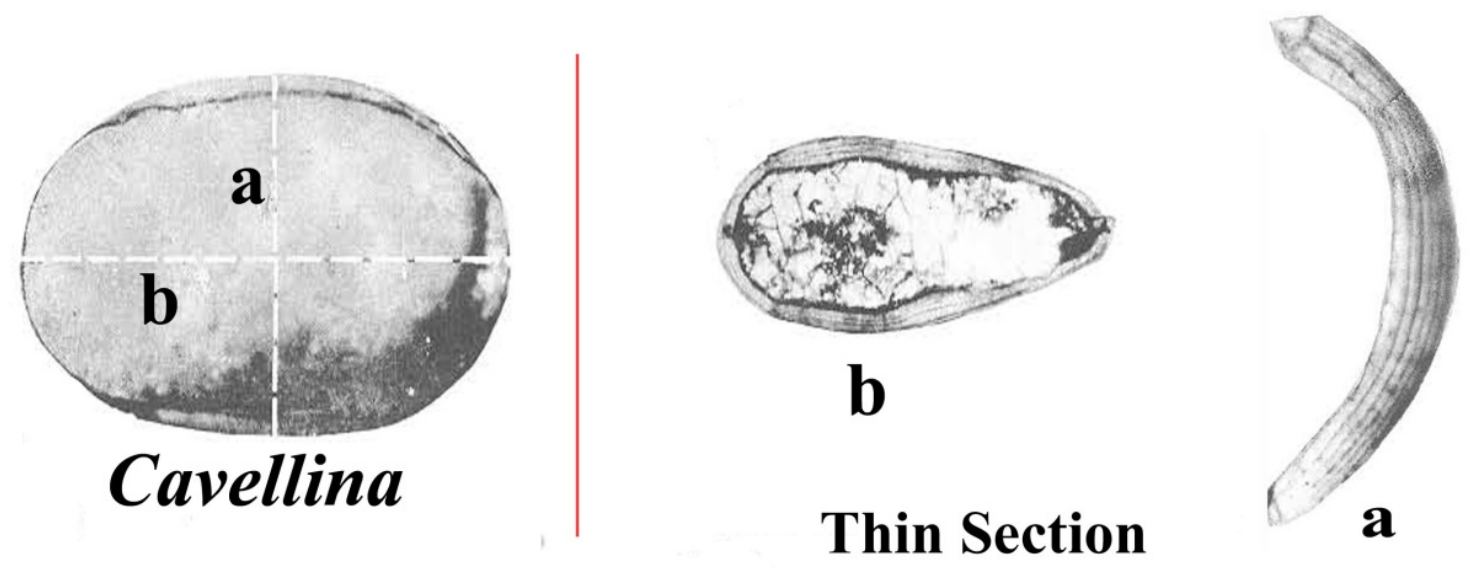

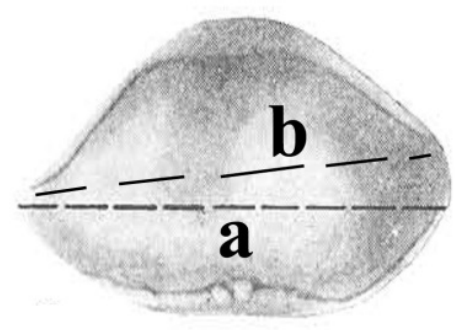

Bairdia

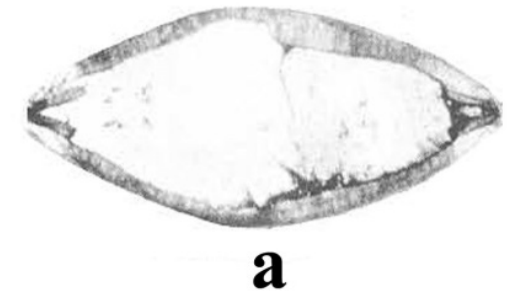

Thin Section

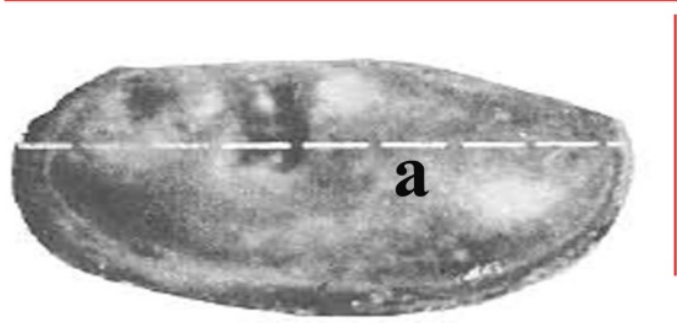

\section{Limnoprimitia}

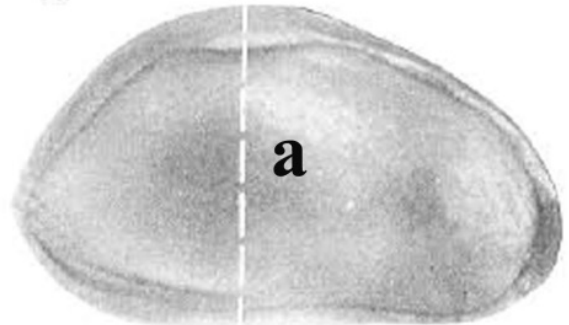

\section{Bairdiacypris}

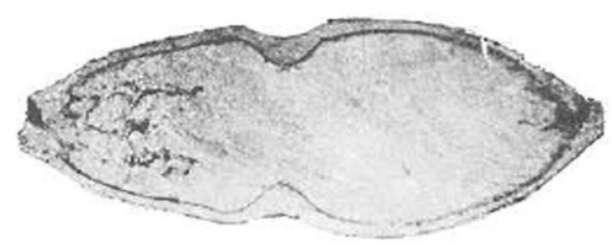

\section{Thin Section a}

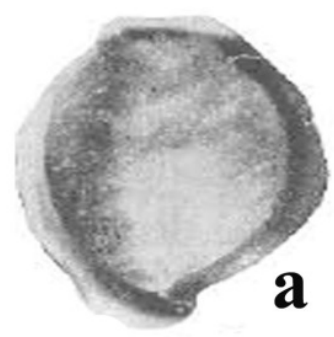

Fig. 3. Photomicrograph shows Ostracoda thin section for some genus Cavellina, Bairdia, Limnoprimitia, and Bairdiacypris

(Sars, 1899 and Moor, 1961). 


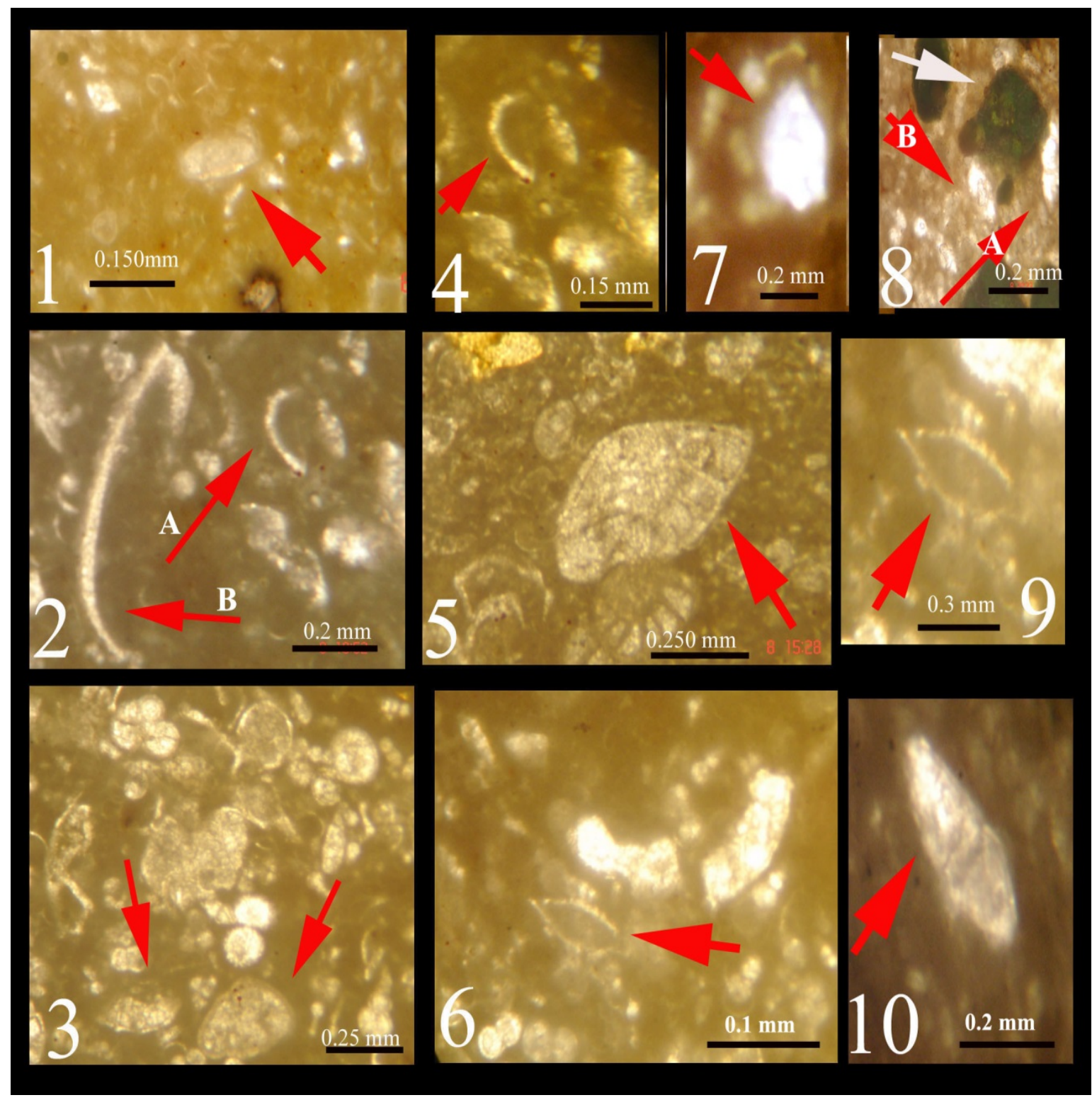

Plate 1. Photomicrograph shows 1. Cytherella sp., samples number KD-3, 4. 2. A. and B. Cavellina sp, sample number KD-6. 3. Bairdoppilata sp., sample number KD-12. 4. Cavellina sp., sample number KD-8. 5. Bairdoppilata sp, sample number KD-15. 6. Bythocypris sp1., sample number KD-5. 7. Pterygocythereis sp, sample number KD-18. 8. Paracypris sp., samples number KD-1, 2. 9. Bythocypris sp 2., samples number KD-5, 13, 14. 10.? Haplocytheridea sp., samples number KD-7, 13. Upper Cretaceous, Kometan Formation, Dokan section. 


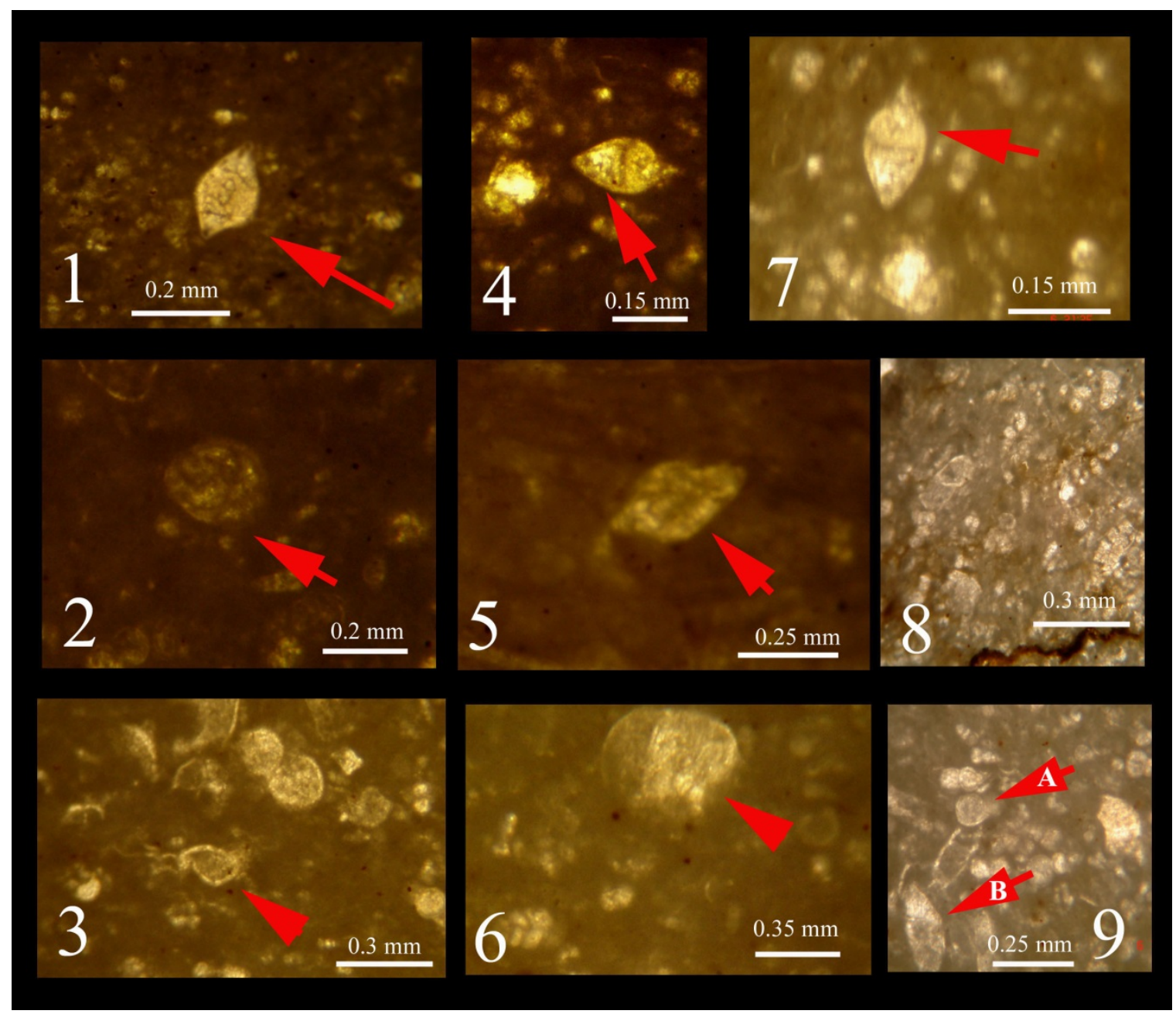

Plate 2. Photomicrograph shows 1. Bairdia sp1., 2. Bairdiacypris sp., sample number KD-6. 3. Cypridina sp., sample number KD-9. 4. Bairdia sp. 2, sample number KD-8. 5.? Bairdia sp.1, sampleS number KD-3, 10. 6. Pterygocythereis sp., samples number KD-4,

8, 11. 7. Bairdia sp.1, 8. planktic foraminifera, samples number KD-3, 12, 15. 9. A. Bairdiacypris sp., samples number KD-13, 14 and B. Haplocytheridea sp., sample number KD-14. Upper Cretaceous, Kometan Formation, Dokan section.

\section{Paleoenvironment}

Ostracoda lived in both marine and non-marine environments. They are recognized from different kinds of aquatic habitats Martens (2001). Some genera indicate the marine environment for instance Paracypris Elpson (1941); Al-Shareef et al., (2010). The present study depends on the Ostracoda genera (Bairdia, Bairdiacypris, Cytherella, Cypridina, and Paracypris), the Kometan Formation deposited in the deep marine environment. The preserved planktic foraminifera Globotruncana linneiana, Globotruncanita stuartiformis, Marginotruncana schneeansi, Heterohelix gobulosa, and Dicarinella asymetrica indicates to deep-marine (Al-Khafaf, 2005) (see Plate 3). According to Al-Qayim et al., 2020, there was no gap or hiatus at the end of the Cretaceous at the Sulaimani area. 


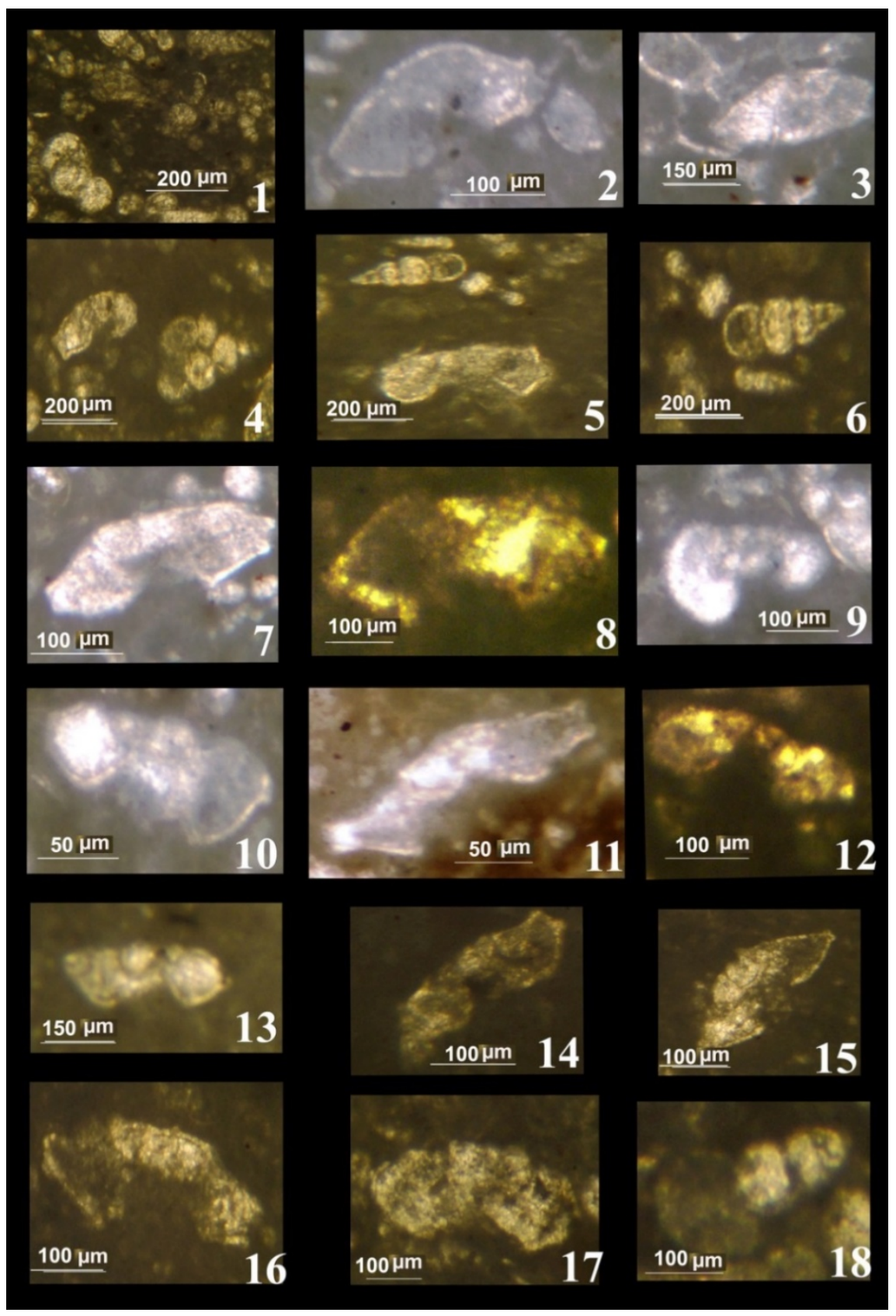

Explanation of Plate 3. Planktic foraminifera of the Kometan Formation. Fig 1,4,6,18. Heterohelix globulosa (Ehrenberg, 1840), sample number KD-15. Fig. 2.

Contusotruncana fornicata (Plummer). Fig. 3. Globotruncana conica (White), sample number KD-10. Fig. 5. Globotruncana bulloides Vogler, sample number KD-14. Fig. 7, 8. Dicarinella asymetrica (Sigal), sample number KD-12. Fig. 9. Macroglobigerinella prairiehillensis, sample number KD-8. Fig. 10. Dicarinella concavata (Brotzen), sample number KD-9. Fig. 11. Marginotruncana marginata (Reuss). Fig. 12. Marginotruncana Renzi (Gandolfi), sample number KD-5. Fig. 13. Globotruncana bulloides Vogler sample number KD-4. Fig. 14. Dicarinella asymetrica (Sigal). Fig. 15. Globotruncanita arca (Cushman), sample number KD-14. Fig. 16. Globotruncana linneiana d'Orbigny, sample number KD-13. Fig. 17. Globotruncanita stuarti (de Lapparent), sample number KD-10. 


\section{Conclusions}

1. The Kometan Formation consists of $127 \mathrm{~m}$ of light grey to white, thin- too thickbedded oligosteginal-globigerinal limestones with stylolite and chert nodules.

2. Thin section studied under polarizing microscopes of the Kometan Formation illustrations nine genera (Bairdia, Bairdiacypris, Bairdoppilata, Cavellina, Cypridina, Cytherella, Haplocytheridea, Pterygocythereis, Paracytheridea, Paracypris) with foraminifera (planktic and benthonic) species.

3. The most important result of this study is the identification of some species of foraminifera in the Kometan Formation pelagic sediments (e. g. Globotruncanita arca, Globotruncana linneiana, Globotruncanita stuartiformis, Marginotruncana schneeansi, Heterohelix gobulosa, and Dicarinella asymetrica).

4. The Ostracoda genera such as Bairdia, Bairdiacypris, Cytherella, Cypridina, and Paracypris with foraminifera species Globotruncana linneiana, Globotruncanita stuartiformis, Marginotruncana schneeansi, and Dicarinella asymetrica indicate the Kometan Formation was deposited in a warm, basin, deep marine environment.

\section{References}

Abawi, T.S., \& Hammondi, R. A., (2006). Foraminiferal biostratigraphy of the Turonian Early Campanian depositional cycle from selected oil wells in Iraq, Anuario do Instituto Geociencias, Jour. Earth Sci., 29: 651.

Al-Shareef, I. Y., Khalaf, S. K. \& Al-Eisa, M. A., (2010). Paleoecology of some Upper Cretaceous Formations from Selected Wells Northwest and Middle Iraq. Iraqi Journal of Earth Science. 10(2): 67-96.

Al-Khafaf, A. O., (2005). Stratigraphy of Kometan Formation (Upper Cretaceous) in Dokan-Endezah area, NE-Iraq. Unpublished M.Sc. Thesis. The University of Mosul, department of Geology, p. 79.

Bellen, R.C., Van Dunnington, H.V., Wetzel, R. \& Morton, D., (1959). Lexique Stratigraphique International: Asie, Iraq, 3c (10a): 333.

Buday, T. (1980). In: Regional geology of Iraq, 1: Stratigraphy, I. I. M Kassab and S. Z. Jassim (Eds) D. G. Geological Surveys and Mining Investigation Publications, Pp. 445.

Buday, T., \& Jassim, S.Z., (1987). Regional geology of Iraq: tectonism, magmatism, and metamorphism. State Establishment of Geological Surveys and Mining Investigation, Baghdad, Iraq, 2: 352.

Chatton, M. \& Hart, E., 1961. Review of the Cenomanian to Maastrichtian stratigraphy in Iraq. OEC, unpublished report, Baghdad. 
Dunnington, H. V., (1953). General migration and dissipation of oil in Northern Iraq. Arabian Gulf, Geology and Productivity. AAPG, Foreign Reprint series No. 2.

Elpson, O. (1941). Zur Kenntnis Der Marine Ostracoden Schwedens Mil Besonderer Bervckichtingong des Skageraks. 2001 Bidr. Uppsala, 1a, 215 - 534.

Jassim, S.Z. \& Goff, J. C., (2006). Geology of Iraq, DOLIN, sro, distributed by Geological Society of London, UK, p.341.

Jaff, R. B. N., Wilkinson, I. P., Lee, S., Zalasiewicz, J., Lawa \& F., Williams, M., (2015). Biostratigraphy and palaeoceanography of the Early Touronian-Early Maastrichtian planktonic foraminifera of northeast Iraq. J. Micropalaeontology. 34 (2): $105-138$.

Karim, K. H., Lawa, F. A., \& Ameen, B. M., (2001). Upper Cretaceous glauconite filled borings from Dokan area, Kurdistan Region, NE-Iraq. Kursiatan Acadmic Journal.

Kaddouri, N., (2001). Microfacies and Microorganisms of the Paleozoic, Mesozoic, and Cenozoic Selected formations from Iraq, p. 148.

Karim, K. H. \& Taha, Z. A., (2009). Tectonical history of the Arabian platform during Late Cretaceous An example from the Kurdistan region, NE Iraq. Iranian Journal of the Earth Science, 1(1): 1-14.

Martens, K., (2001). Ostracoda. In: Guides to The Freshwater Invertebrate of Southern Africa, Vol. 3: Crustacea II, (Cahpter1), INRC Project (Chapter One), 916: 9 - 77.

Moore, R. C., (1961). Treatise on Invertebrate Paleontology: Arthropoda 3: Crustacea, Ostracoda; RH Benson [and Others]. Part Q, Geological Society of America.

Sars, G. O., (1866). Oversigt of Norges marine ostracoda. Forhandlinger I Videnskabs Selskabet i Christiania, 7:1-130.

Al-Qayim, B. A., Kharajiany, S. O. \& Wise, S. W., (2020). Biostratigraphic analysis of the K/Pg boundary using calcareous nannofossils from the Sulaimani Area, Kurdistan Region, Iraq. Kuwait Journal of Science \& Engineering, 47(4): 92-105.

Taha, Z. A., (2008). Sedimentology of Upper Cretaceous Formations in Kurdistan Region, NE-Iraq. Unpublished, MS.c thesis, University of Suilaimani, p. 132.

Submitted: $\quad 05 / 08 / 2020$

Revised: $\quad 11 / 01 / 2021$

Accepted: $\quad 12 / 01 / 2021$

DOI: $10.48129 / \mathrm{kjs} . v 49 \mathrm{i} 1.10265$ 